Open Access

\title{
Cyber-security in smart cities: the case of Dubai
}

Marios-Panagiotis Efthymiopoulos

Correspondence: marios.

panagiotis@aue.ae

Assistant Professor of Strategy and

Security, College of Mass Media and

Communication, American

University in the Emirates, Dubai,

United Arab Emirates

\section{Springer}

\begin{abstract}
The city of Dubai emerges as a leading partner in not only technology innovation but also designed infrastructure and strategic security. There is a strategy, which will globally add the city and leadership to the leading smart cities of the world. Considering current and future challenges, the strategic aim is to 'smart' wire the city of Dubai by 2020. Dubai is a city of strategic technology, innovation and management. It is a global, vibrant and emerging economy among others, that can become an economic hub of the MENA (Middle East and North Africa) region. The aim of this paper is to explore, analyze, and discuss elements of strategic management, innovation, development. It is also the aim to discuss elements of strategic security, in making the city is cyber-secure in a smart networked infrastructural and service provider, environment.
\end{abstract}

Keywords: Cyber-security, Development, Democracy, Smart cities, Infrastructure, Dubai, Dubai model, Expo 2020, Strategic planning

\section{Background}

The Dubai model is a success. It is, by 2015, exported as a source role model for development; an ultra-post-modern and futuristic socio-political and economic structural and infrastructural system that brings balance, stability, and ultimately, security: The current city development of Egypt's "New Cairo" project, through the support of the UAE, is a prime example of outsourcing the Dubai's development model of success. ${ }^{1}$ Dubai's technology advancement, security infrastructure, and innovative planning and action develops through a strategic development model, in which Dubai aims to lead on the global development of "emerging hubs" (Lerner 2013). Its aim is to now become a smart city. It will boost economic Islamic development on behalf of the Middle East and North Africa (MENA) region of where 1.2 billion people reside, among which, many thousands of expatriates. "Wiring" attempts are already attempted. The strategic aim is simple: to be able to use all services and all government institution and authority services, to start with, through a single touch of your cell phone screen. It is an innovative way for simplifying services and lifestyle. This is the Dubai approach.

Challenges are being met through opportunities which constantly arise. The strategic plan is to give way to true innovation and technological advancement, through an emerging market epicenter such as Dubai, and to provide development, stability, and security. Dubai's smart city, the Silicon Oasis Smart City initiative, ${ }^{2}$ is currently being developed to meet the not long future needs of the Dubai Plan 2021.

(c) 2016 Efthymiopoulos. Open Access This article is distributed under the terms of the Creative Commons Attribution 4.0 International License (http://creativecommons.org/licenses/by/4.0/), which permits unrestricted use, distribution, and reproduction in any medium, provided you give appropriate credit to the original author(s) and the source, provide a link to the Creative Commons license, and indicate if changes were made. 
This paper attempts to explore and critically analyze the Dubai strategic development city model. As per the interests of this model, it concentrates on the smart city initiative design and application for the city of Dubai. It will also project the need for smart cyber-security.

Dubai is the model city example, per the needs of this current paper. Twenty-first century security and stability in the MENA region is projected through this city which provides innovation and strategic development in reality. The paper describes not only the current but also the future needs of the MENA region and its people. The described and analyzed model of this paper will be surely exported in other countries in need. It will have a direct interest to global governance and regional security. It will allow for direct foreign investment (DFI).

This paper holds a multi-disciplinary approach. It puts forward combined proposals in the field of business and economic development, security, and strategic management processes. It reflects the topic of grand strategy and security, innovation, and infrastructure. It is a paper that explores the city of Dubai and adds value to the new policy orientation of cyber-security in the strategic attempt to make the city smart and on the way for Dubai to welcome the "Dubai 2020 World Exposition". ${ }^{3}$

\section{The epicenter that is called Dubai}

Dubai is a vibrant city. ${ }^{4}$ It is a new city. A city which competes itself in infrastructure, services, and goods, complete with multi-national and multi-cultural environments. Dubai is one of the new and emerging "lands of opportunities", an emerging world, merged in a single city, complete with ideas and suggestions that are actually put to the test in a globalized and multi-cultural environment.

Dubai is a city of both innovation and luxury at the same time. It is a city of ultramodern architectural design in its complete infrastructure. The design of the city and its already offered services are carefully selected and constructed. It is an innovative engineered city, from its sewage system, which is applied in former desert and moving sand area in a new environment and structures that fit the needs of newly coming residents, which are ever increasing in numbers. ${ }^{5}$

Dubai is a crossroad, a new world city that supersedes expectations on global living standards and affordable services. It offers clear lifestyle, luxury combined with architectural innovation, high-level and high-tech services, while living expenses are skyrocketing year by year making Dubai one of the most expensive cities to live in. "Over the last decades Dubai, has applied an economic development model which is strongly pro-business, emphasizes market liberalism and economic openness, and embraces globalization..." (Hvidt 2011).

Today, Dubai is becoming a large and global market competitor, a hub of transport and services (Hvidt 2011). Its citizens, in its majority expatriates (expats), count as $8,264,070$ in a 43-years-of-age country. Its local population, "Emirate Nationals" count according to the National Bureau of Statistics and the most recent census of 2010 as 974,997 peoples. $^{6}$

The United Arab Emirates (UAE) was and is envisioned through its founder Sheikh Zayed bin Sultan al Nahayan, whose dedication was to preserve architectural and living 
heritage (Schneider 2012). The UAE's strategic vision today in its global form promotes not only UAE's heritage and culture but also a global cultural development, processes and actions through innovation, and smart-thinking, planning, and action. The United Arab Emirates comprises seven emirates, Abu Dhabi, Ajman, Dubai, Fujairah, Ras AlKhaimah, Sharjah, and Umm Al-Quwain, located along the southeast coast of the Arabian Peninsula. The country covers an area of around $84,000 \mathrm{~km}^{2}$.

Dubai, which is the capital of the Emirate of Dubai, according to Hvidt, has shown that through innovation, strategic investment, branding, and openness to globalization, Dubai has been able to transform a backwater, oil-poor Arab city-state into an international metropolis. ${ }^{8}$ Today, Dubai seemingly competes itself. It also wants to compete with the world in the fields of innovation and technology through prime-provided services and infrastructures. Dubai, as New York, is a city that "never sleeps". Dubai is a "production machine city". A city of branding elements that combine and merge with each other and visionary approaches that come to being in practice. Complete with engineering plans, from city landscape, architecture, social commodities, and now, social infrastructures, Dubai is an example city of innovative methodological and practical approaches to what we may call true city and country development. It offers to the locals an increasingly emerging GDP per capita and per family, so as also to the expatriates joining forces, while they wish to mix with a multi-cultural, multi-religious, and multinational environment truly from around the world. Dubai's anthropological idiosyncrasy projects how big in population, cultures, and civilization the planet is, a social structure that is bonded by the global rules and regulations of the international community; while respecting local religion, culture, and heritage, it offers true opportunity to those that seek to not only invest but also innovate while Dubai is increasingly becoming a hub between the Western Hemisphere and the Eastern Hemisphere. ${ }^{9}$

Dubai, whose actual name according to the local national Emiratis is pronounced as Dubayy, is one of the most popular cities in the world. ${ }^{10}$ Its geographic location's coordinates are $25^{\circ} 15^{\prime} 8^{\prime \prime}$ North, $55^{\circ} 16^{\prime} 48^{\prime \prime}$ East. Dubai is part of the United Arab Emirates; the Emirate of Dubai, which counts as one out of the seven Emirates, is now set to become a "smart city" by the year 2020, according to His Highness, the Vice President of the UAE and ruler of Dubai, Sheikh Mohammad bin Rashid Al Maktoum. ${ }^{11}$

\section{Discussion}

\section{Strategic development of Dubai}

Dubai is a business hub for the Arab Peninsula and the MENA region. By the 1960s, Dubai's economy was based mainly on revenue from trade, whether trade was associated with sea trade and old historical desert trade elements. However, oil discoveries by 1966 made both Dubai and Abu Dhabi the key source, from which revenue would flow, starting 1969, for the city of Dubai. ${ }^{12}$

Oil revenue accelerated actual true development for the city of Dubai, for the short term, adding Dubai to the world map of developing and emerging cities. Up to the day of oil discovery in 1966, Dubai was known for its port trade, through the old city and port of Deira and through the gold market "Souk" mostly known for diamond hubs and 18-ct gold with great clarity in its gold trade. Oil, nonetheless, would soon become the key aspect value for money, giving way to a strategic plan for construction and 
mass development in infrastructure, service providence, and transport hub, making Dubai a western, global-friendly, capitalist city.

An innovative model economy of architectural design, services, and later on, innovation would seemingly emerge, as a possible driving force for true development. ${ }^{13}$ Its true fast-track development would offer the thought of a true leading, initially the Arab Peninsula region of emerging countries and forward in the years to come, the Middle East, totaling an opportunity for growth which counts today as 1.2 billion people, a great emerging market share considering both the opportunities to expand and grow but also the emerging trade agreements with other emerging economies, mainly in the Asian regions and the African developing regions.

Oil reserves supported all strategic options for fast-track actual growth in all levels of necessary social and market structures. Its strategic location as it stands today is an "association between market orientation and business performance" (Ben Brik et al. 2011). Long-term and grave geostrategic and geopolitical changes of the twentieth century provided an opportunity for Dubai, to raise a modern and safe city in a strategic location giving way to the twenty-first century intelligent, high-tech, high-level architecture and services that bring about a sense of psychological security among others.

Many assume that Dubai is solely an oil revenue city, but it is not. It is also an exporter of services and now innovation and safety procedures. Dubai could not assume a leading position and would never render a leading position if it would not sign for a long-term executive and strategic plan of and for global development. Dubai forecasts innovation and technology. It combines lifestyle and smart applications among others. It is secure and stable. Dubai can render a dream of lifestyle into reality while making sure all elements of futuristic progress is applied.

Dubai does not lack any sources or materials. It has great services and is a great service provider. It is a competitive global-friendly city. Dubai is a capitalist city, which very soon will emerge to become a key point for contact on global trade and effective engagement. Dubai's capitalist system is believed to now have given way to a new corporate structure, a corporate relations framework, and social-global reconstruction, through economic and technological advancements, the aforementioned elements being the three key elements of multi-civilizational success and corporate or social responsibility actions (Ben Brik et al. 2011). The emergence of these emblematic elements of societal and large and impressive structures of this modern day city now projects slowly giving way to service providence, making sure Dubai remains an attractive place to invest and to live in.

Dubai is a vibrant city, effective and creative. It creates or upgrades all necessary infrastructures. Through organograms, it allows for multi-layers of services and action plans which come into reality. Dubai's grand strategy estimates on how and what the city should look like, feel like, and what it takes to be offered or constructed which will bring a constant and continuous change. Dubai, as a global city, interacts as a strategic focal point with today's world system of governance (Acuto 2010a). Its actions make the city world renown. Its Executive Council is chaired by His Highness Sheikh Hamdan Bin Mohammed Bin Rashid Al Maktoum, Crown Prince of Dubai, seeks innovation and excellence, reaching governance to its best and highest quality framework. ${ }^{14}$

Depending heavily on its million strong workforce coming from countries of the Eastern Hemisphere like India (Meyer and Brysac 2011), Dubai is set to meet social 
and religious global needs, with which it will inaugurate a new era of constructive change, to meet global expectations and a competitive market for the twenty-first century which are concentrated in around specific elements of stability, security, and excellent lifestyle residency expectations.

A grand strategy for Dubai had to take place. The city, by 2015, is looking ahead to its grander role as a stabilizer of regional and global trade, program and action planning, resourcefulness, social openness, stability, and security in a constantly changing geostrategic world, a city complete with technological advancements and innovation ideas, processed through a new platform named as the epicenter of development and application, a smart city.

The paper will describe and analyze in a multi-level and multi-disciplinary approach the "epicentric" needs of the twenty-first century Dubai, a research which was conducted during the complete year 2015. This research paper combines not only the elements of meeting the trade and high technology demands for the 2020 World Expo objectives but also the 2021 world technology objectives. ${ }^{15}$ This research paper is both an analysis and description of a modern day successful, going "smart policy", which potentially can turn into becoming the Silicon Valley of the Arab world of 1.2 billion people, notwithstanding neighboring continents which now profit solely on the relevance of the location of the city of Dubai.

As a non-disclosure statement when considering this paper, the author would like to state that this work is entirely, and to its complete completion, under the responsibility and authority of the author. It does not represent any government or university policies. These are results and ideas of the author derived from his ongoing experiences, work, and research, while residing and working in the city of Dubai as an assistant professor of international strategy and security at the American University in the Emirates. No research outcomes are therefore associated with any entity, institution, and organization but are sole opinions and responsibility of opinions of the author himself.

\section{A grand strategy for Dubai: the World Expo 2020}

In order to achieve goals in the city of Dubai, one should have a clear overview of the strategic objectives of what Dubai aims to become. Strategy, being one of the oldest policies in the world, mainly known for military and security purposes, applies today as well to the market world, whether this is for development or other purposes, like marketing, management, and public or international affairs. ${ }^{16}$

The World Exposition of $2020^{17}$ was a bid for the city, one of all to come, that would welcome in a yearly venue of more than 30 to 40 million people, exhibitors seeking to trade, to coordinate, and to meet other potential collaborators and seek potential cooperations. Following the example of major cities for world exposition making trade the sole authority for first contact and knowledge between other civilizations, something the Arab world knows about quite well, Dubai follows the need for major events, which would request quite much change in current infrastructure and positioning of the government and its residents residing in the city. Following the first attempt of a world exhibition initially, held in London in 1851, the World Expo "aspires and strengthens connection.... It celebrates diversity and marvels at technological advances". ${ }^{18}$

The world expo is handled and exposed every 5 years to the global public not limiting all cities to have other world exhibitions. Nonetheless, world exposition makes each city 
that organizes the event an important city which is of global attention, and in the developing world, such important events give rise to a fast-track change and request for current structures to be improved while new ones to be associated with.

A focal meeting point for sharing innovation and technology, progress on programs of global concern, economic prosperity, world peace and security, sustainable growth and development, and direct foreign investment are some of the few elements of a world exhibition city, which welcomes such events. They all run parallel to the global venues of constant and yearly run trade fairs. For the year 2020, Dubai will host the world exposition for the first time since its creation as a vibrant city. It will market for the first time the world's fair in a region that has not been associated with global trade rather than a local trade and point of service hub, marking Dubai as the global connector or world fair to be hosted in the Middle East, Africa, and South Asia.

In a new landmark in the city of Dubai, the "expo city of 2020" will run for 6 months, according to the organizing committee from October 2020 to April 2021, marking along the opportunity "the $50^{\text {th }}$ Anniversary Golden Jubilee celebrations". The exposition has a three-framework marketing and smart theme: Connecting Minds = Creating the Future", while Dubai seeks to re-invent the levels of social and corporate cooperation, services provided to the citizen, the resident, and the tourist through the touch of a button, through the thought of having a relaxing lifestyle, a living standard through an "Anatolian-Arab understanding". 19

For the complete set, the concept making and the centerpiece of exposition 2020, Dubai is named as Al Wasl Plaza, after Dubai's historic name of "connection". State-ofthe-art exposition pavilions are being created, interactive effects and journeys around the globe in a single city that is now united and combines effective decision-making with state-of-the-art construction is the sole objective of the city. In this attempt, more than 30,000 volunteers will render Dubai an innovative city, a city of growth, development, and innovation, combining smart achievements and a new infrastructure as a model of world heritage and culture.

In a state of technological interstateness and interconnection, where physical boundaries in the age of technology are no longer there, in an increasingly globally challenging environment, where geopolitical and geostrategic changes occur, Dubai is set to become "a platform for connectivity to help pioneer partnerships for growth but also sustainability" for future people and future generations.

\section{Where sustainable growth borders smart city}

Dubai's Executive Council, ${ }^{20}$ which was established in 2001, will head on with strategic growth projects. It has major strategic goals put in place; to manage projects in an effective way, it combines effectiveness, positive outcomes, and technological and architectural advancements for the benefits of its residents and to also meet through project creation and making the sustainable growth environment requirements as put forward by the United Nations and committed by the UAE government. Major events, major works, and mega projects being sustainable and technologically advanced would testify for a prime and futuristic society, a society which is constantly on the move and constantly requests a swift and complete change in an emerging city with a multi-national and multi-cultural society. 
The design of a sustainable growing city borders on the need for far-reaching commitments of energy and construction friendly to the environment, affordable and technologically advanced to the point of smart city goals and framework. The aim is to make Dubai or regions of it "smart" facilitating growth and knowledge through innovation and research. ${ }^{21}$

A city in which all elements from basic transport, to infrastructure, business and government services are complete and interconnected with each other, connection and increased cooperation between people, business, and government is completed in an easy way. Through the touch of a button, through a cell phone, residents should be able to resolve all their standing issues with the government.

The promotion of smart cities is a development plan for the residents and tourists visiting Dubai. Dubai positions itself as a city where technology meets the requests and needs of the twenty-first century, which is the century of technology, whether these are complex or simple requests, of and for everyday life and business.

It promotes government effectiveness and allows for smart facilities. The aim is to facilitate as much as possible the government and the residents in request of information and or support by the local or UAE government. As such, sustainable growth is met through development of energy and water efficiency with quality building standards both environmentally friendly and ready for smart use.

The creation of the International Renewable Energy Agency, headquartered in Abu $D_{\text {Dhabi }}{ }^{22}$, is part of a wider effort of the UAE to meet the commitments to the United Nations sustainable development. ${ }^{23}$ Therefore, within the smart city initiatives of cities in the UAE, the capital Abu Dhabi and the city of Dubai, among other emirates, now aim to combine effort and activities to meet the high standards of living but also affordable and sustainable living for the twenty-first century. These are globalized cities and "metropoles", in which among others "impact the global environment... organize and regulate worldwide, regional and national flows...have a strategic governance capability...and have the capacity to entertain representative as well as advocacy, relations with other entities..." (Acuto 2010b).

\section{The Smart City Initiative of 2013 and beyond}

According to Dubai Media news services, the city, by July 2015, is getting closer and closer to becoming a smart city in practice ${ }^{24}$, in its wide network of both government entities and city infrastructure. The Dubai police Traffic and Crisis Management Control Center, which observes and reacts in case of a crisis management, has by now managed to connect all 408 signals of the Road and Transport Authority with the operational center ${ }^{25}$, an operational center which works based on the city-wide attempt to use $3 G$ and $4 \mathrm{G}$ technology to wire all necessary infrastructures for the daily road and transport effectiveness of the city. The completed work is part of the Smart City Initiative of 2013 for a stronger and safer infrastructure of the city. ${ }^{26}$

Considering the aforementioned example case, all necessary work to the infrastructure "grid" on the road and traffic signals has been already completed and new projects are to follow which will "wire the city". The new system of control of signals, as an example, is now linked through new grids and lines that are energy-efficient, easy to comprehend and use, and easy to be maintained. Possible "glitches" seem to be minimized but not eliminated, at which point we should consider possible security risks at hand in 
terms of smart security and or cyber-security policies to Dubai's current city and grid infrastructure.

The Smart City initiative was announced in May 2013, according to the Vice President and Ruler of Dubai, Sheikh Mohammad Bin Rashid Al Maktoum, Vice President and Prime Minister of the UAE and Ruler of Dubai where all or most government agencies, need to be centralized and most importantly available online; giving surely rise to a new element of research in which one may wonder about the security effectiveness in a wired-world: "Dubai Smart Government Department operates in harmony and integration with all the departments and entities that come under the Government umbrella in Dubai...Initially called Dubai eGovernment, the Department's name was changed in June 2013 to Dubai Smart Government, by HH Sheikh Mohammed Bin Rashid Al Maktoum, UAE Vice President and Prime Minister and Ruler of Dubai in line with his initiative to transform to an era of smart government". ${ }^{27}$

By October 2015, the Dubai Government now offers direct public services, followed by the private sectors, including banking, transport, and logistic and tourism services and companies. The electronic format is concentrated in the form of smart applications, which we can use through our cell phones. All applications hold a complete capacity and can manage service requests. They simplify everyday life in Dubai and offer residents and tourists quality services. Practically, this means that the Dubai government now offers over 2000 government services online, which are constantly updated for the needs of the residents and the citizens within the United Arab Emirates.

\section{Dubai's Strategic Plan 2015-2021}

By 2014, Dubai's Ruler His Highness Sheikh Mohammed Bin Rashid Al Maktoum along with the Chairman of the Executive Council of Dubai, and Crown Prince of Dubai His Highness, Sheikh Hamdan Bin Mohammed Bin Rashid Al Maktoum inaugurated the Dubai Strategic Plan 2021. ${ }^{28}$ Following the successful experience of the former Strategic planning of 2007, which would come to completion by 2015, would render Dubai's growth in practice in the following areas: trade, logistics, financial services, and tourism, which would in turn, attract the city of Dubai as a major investment city and therefore would allow global and local social services to develop.

By October 2015, the Strategic Council of Dubai has launched a global story of branding, marketing, management, and investment in which through an important social structure and platform of development will render Dubai as "the preferred place to live and work, for people and visitors alike". Dubai's branded position as a global city now allows for what is expected as the "foundation is laid" for capacity building, creativity, innovation, and certainly prime research to create "a truly special future" for Dubai.

According to the Strategic Planning, Dubai's development framework by 2021 includes development in the sectors of the economy, the society, the people, the experience, the government, and lastly, the place. ${ }^{29}$ Each framework of model policy is associated directly or indirectly with each other. Success can be complete if all joint frameworks are successfully implemented. Considering the interests and the importance of this research paper, we will lay importance and interests to the three following sectors: the government, the experience, and the place. They interrelate and correlate with each other. Through an analysis of each framework, we will be able to compile the 
elements that need to be projected, namely in the field of cyber-security and cyberdefense for a smart, engaged, and futuristic living Dubai.

\section{The government}

Dubai's Smart Government, as aforementioned, goes hand in hand with the Dubai Strategic Framework of 2021. The latest describes "the future of Dubai, through holistic and complementary perspectives". The framework is divided into six sectors that are named as "themes". Three of which interest the purpose of this research: The theme of "place" discusses, proposes, and analyzes strategic aims and goals towards a more smart and sustainable city that we need to be aware of. The other two include the government theme and the experience theme. Each theme has performance indicators for which all strategic changes will apply for. Below, we describe and briefly analyze each to comprehend the levels of development that actually Dubai is or seeks, while keeping in mind the fact that an e-security policy needs to be adopted for the protection of a truly modern and technologically advanced city.

Smart and sustainable city:

For the theme of smart and sustainable city, the key performance indicators are based on the following elements:

- "Satisfaction with the current Dubai city infrastructure

- Rate of carbon dioxide emissions per GDP

- Annual solid waste generated by the city per capita

- Average response time to different emergencies of police, civil defense, and ambulance

- M-completion

- Road fatalities per 100,000 population". ${ }^{30}$

The theme considers the following important elements consequently of interest to this current research paper: the focus on building a fully connected and integrated infrastructure that ensures easy mobility. The aims are as follows: towards a safe and resilient built environment with updated safety standards for crisis management response and capacity building for the futuristic city environment and envisioned connected e-world.

The Government theme:

The government theme requires a smart, diligent, but easy going system of governance, a quality framework application method in support towards the citizen, resident, and tourist visiting or residing in Dubai. That is why governance of Dubai requires pioneering and excellence. Key performance indicators include:

- "Satisfaction rate with the quality of city's services

- M-services adoption index

- Budget surplus/deficit as \% of GDP

- Government efficiency index

- Proportion of government building that are green certified

- Rule of law index

- Proportion of individuals who have confidence in the judicial system and the courts

- Proportion of individuals who have confidence in the local police". ${ }^{31}$ 
The theme considers a proactive engagement for both the "individual" and the "institutional" requirements. It also aims to provide high-quality e-services to the people. Yet, it does not clearly refer to precautionary measures or established policy of eprotected methodology of government services for the institution and the government itself, while it also protects and assumes e-based and web-based protection for the citizen/resident of Dubai.

The final theme is Dubai as a preferred both destination and living place to be.

Key performance indicators include:

- "Proportion of individuals who are satisfied with the quality of educational services

- Proportion of individuals who are satisfied with the quality of health services

- Proportion of individuals satisfied with the availability of good, affordable housing

- Proportion of households living comfortably with and getting by on their current income level

- Proportion of individuals who recommend Dubai to a friend or associate as a place to live

- Quality of Living Index (Mercer• Sense of security in Dubai

- TIMSS results of international assessments for all students

- Number of violent crimes per 100,000 people".

Dubai's high-quality living standards necessitate the continuation of a security place to live at. ${ }^{32}$ ]s The feeling among citizens/residents and visitors in Dubai is that the city is wired with immediate security collective and personal, with all necessary infrastructures put in place, constantly upgraded with new tools being applied, some of which should include, except enforcement law, e-governance and security framework of all web-based services and government and city infrastructures.

The expected outcome is expected to impact positively all in Dubai and other neighboring cities. Awareness, knowledge, and information tactics and daily operations should be put to plan and to the test. Dubai is set to complete all actions for a strong and secure development that will identify and drive the city to be nominated among the best cities in the world.

It is therefore essential to stress the levels of a sound and secure preparedness for a city that (1) never sleeps, (2) always develops (3), where innovation meets research application (4), and where grave geostrategic and geopolitical global changes give rise to opportunity.

A strong city planning requires all possible scenarios and eventualities to be taken into consideration. More so, when a city such as Dubai seeks an e-wiring process that is expected to both render the individual and the institution both safe but also dependent on the possibility of an electronic attack that may compromise the expected levels of security approach.

\section{Results}

\section{Cyber-security and smart city}

In 2014, the Vice President and Prime Minister of the UAE and ruler of Dubai, His Highness Sheikh Mohammed bin Rashid Al Maktoum has issued Law no 11/2014, establishing the "Dubai Centre for E-Security". ${ }^{33}$ 
According to the "mGovernment Magazine", the center is "a corporate body and enjoys a legal status, financial and administrative autonomy. It aims to protect information, communication networks and government information system in Dubai. It aims to develop and modify the use of necessary means in the e-security, and develop efficient ways to saw and swap information among all authorities in the emirate". ${ }^{34}$

The e-security center will work on the basis of providing the technical tools and efficiency in logistical support for all government entities in Dubai, while at the same time protect the citizens, residents, and tourists arriving and/or residing in Dubai. It is tasked to go in parallel with the strategic goals of Dubai to continue being a safe and developed city, a strong hub and a center for trade, culture, and high standard of living.

The capability framework includes coordination with all government entities, cybercrime protection mechanism, and a proposed center for e-regulations on e-security and safety. Knowledge and awareness are complementary efforts which will allow the center to take part and joint cooperate in multi-educational levels of cooperation.

The center would run as a coordinating and regulatory evaluation authority, which upholds the national and city laws, in order to follow the rules and regulations, to complete tasked cooperation with each authority to reach a security-level approach towards e-security and e-governance protection methodology.

The center would set up a strategic plan to fight possible current or emerging threats. To secure and implement methodology for all government agencies as well as business organizations and institutions to protect, to interrupt, and to secure the grid networks whether these reflect the communications networks or the information networks coming in from each system.

The center complements efforts of the Emirate National Electronic Security Authority (NESA) ${ }^{35}$ to which it "liaise" and collaborates with, which is the protective authority for all national security authorities in the United Arab Emirates.

All of the above concentrated have allowed for the center to get a regulatory body accreditation, which is obtained by decree by the Ruler of Dubai and tasked to both implement protection practices and develop the city and its plans for sustainable growth among others.

\section{Lessons learned}

Lessons learned show that current and future challenges require agility and forecasting. There is an option and opportunity for Dubai to lead the e-world of smart cities among others, notwithstanding the fact that leadership requires tangible ideas and tangible innovative results. We may therefore propose that the center be tasked on the following preventive policies, for a safer "e-environment". Consequently, we propose the following:

1. To potentially enable a complete and total protection of the city as a strategic plan through authorized methods based on the current decree.

According to Frost and Sullivan, cities which become smart and are 26 to this point will become shareholders of a market of potential global revenue to be shared, which counts according to the report $\$ 3.3$ trillion by the year 2025. Making knowledge, innovation, and application a must, Dubai should be expected to become a complete 
protected e-city by 2020 . It should coincide with the primary goal of the city's success towards the upcoming World Expo. ${ }^{36}$

\section{Recommendations}

Dubai needs to meet the trajectory requirements of an e-safe environment by 2021, which will mark the end of the currently ongoing strategic development plan of the city, therefore giving way for the upcoming strategic agenda of 2021-2028, to concentrate among others to specific challenges of technical use pertaining to the constant upgrade and update of e-security and defense policies.

Acknowledging current and emerging international and geopolitical challenges, issues of research and application for an e-security framework should be expanded to beyond the telecommunication and network grids, so as to include the current and future cloud technology, mobile and eGovernment smart applicationsas well as applications from institutions and organizations, such as banks or schools, current and future drones, but also printing and of robotic and defense development on robotics and space innovation and exploration.

2. The center should concentrate on the actual agenda of the security threats and vulnerabilities as they exist today, creating a sensor statistical information center for all concerned e-policy concerns, among others including:
a. Application vulnerabilities
b. Malware
c. Hacking
d. Third parties/mirroring
e. Organized crime
f. Cyber-terrorism
g. Cloud-based services
h. Against state-sponsored acts ${ }^{37}$

3. The center should be accredited among other cyber-centers of e-protection and cyber-defense, through cooperation and innovation inside both the framework of smart-defense and strategic planning ahead for Dubai. There should continue to be a constant research demand to share knowledge and appropriate information with appropriate clearances. As current perspectives may possibly not reflect current or future needs that we may not be aware of just yet.

4. Concerns still persist in developing worlds, according to the Global Information Security Workforce study, which concludes that the policies of emerging security and protection activities should be aligned with many high priorities of organizations. ${ }^{38}$

\section{A grand strategy on cyber-defense and cyber-security in smart Dubai}

Smart Dubai requires a smart policy engagement including the cyber-defense and cyber-security sector. This entails the possible creation of a knowledge and research center for security, stability, and protection methodology. Tactical and operational knowledge should be a must. Information should flow as should knowledge-based national intelligence and international intelligence framework that would support action for a Smart Defense policy framework. 
Cyber-attacks be assessed and evaluated in multi-levels through multi-scenarios. Therefore, a training center for crisis management and operations evaluation and training should come to existence. A possible hack or attack to the main infrastructure may increase the risk of actual damage. It will render the current strategic plan as outdated although is already ahead of its time and futuristic, considering the emerging needs of the current strategic security and stability both in the UAE and in a city such as Dubai which is deemed to become a leading smart city. This city will be expected to provide evidence of security and stability while it will increasingly share global revenues, while elevating lifestyle in the city both in "analogic and digital ways". Primary research over the years in a variety of countries, including now the United Arab Emirates in the strategic and security fields, provides evidence that there is an increasing need for coordination of human factors related to issues of electronic defense, operational network intelligence, cloud protection, airspace protection, and smart robotics not to forget new and emerging policies such as use of out of earth space and outer-space exploration and therefore protection of national data and information.

There is a need for a Smart Securitization policy. A national Cyber-Security policy which will safely secure and constantly update protection methodologies of the city of Dubai and which may be elevated as a national policy in the United Arab Emirates. A national cyber-policy will conceptualize, concentrating on the current and futuristic regions, and will conduct a risk assessment and risk analysis of emerging threats coming as a consequence of the emergence of the city and the country, considering its geostrategic location. It should look at the strategic and growing necessity for constant protection against current and future challenges.

A Smart Defense policy should be created. It should comprise all the practical, legal, political, and military needs of the United Arab Emirates combined and interoperable, which may not at this time be anticipated. It should be an idea or procedure to be foresighted, considering the emerging unstable regional and global environments.

Operational needs and expectations should be pointed out, tactically and operationally, providing a clear "road map" for success. In turn, the Dubai authority and the center for e-security should adopt rules and scenarios for engagement methodologies, a doctrine of engagement that will satisfy legal national and international actions to deliver immediate results when something unlawful happens.

\section{Conclusions}

In a period of export-developing models according to the rulings and the wishes of the United Arab Emirates, as a role model to the MENA region to start with, practically more can be done to assure smart city, security, and defense for Dubai, leading to the World Expo 2020 and beyond.

A smart city and therefore, smart-securitization of all e-networks and infrastructures, will lower possible current costs in daily operations and human capital. Any possible cost will be associated with the value of services provided. e-security and e-defense will become part of the smart city allocation of revenue, rendering more assets to the city of Dubai, while it will allow for global cooperation and sharing of information and from a point on expertise work.

Cyber-security should become a key stake-holder policy and should therefore be called UAE smart defense policy, if considered national, more than the city borders. UAE 
national security policy should have a clear city mandate and a national mandate along with the national identity authority and the ministry of interior and defense (News 2014).

Cyber-security is an effective policy, which will attract more attention to international collaborators and in which place will allow for technological processes and progress in action while Dubai continues to be a safe, secure place to live and work in, while leveling constantly with the needs and the requirements of a world by now complete with technological advancements and opportunities to possibly create damage.

The paper brought to light the current situation standing in Dubai as a much anticipated smart city, which holds a complete network of smart infrastructure in place and is set to do more to comply with the ongoing and emerging challenges of the twentyfirst century. Described and analyzed in a multi-level and multi-disciplinary approach, Dubai's needs of twenty-first century, a city of economic center, trade, but also culture, standard of living and an international community meeting point should be assured through all protection methodologies both analogic and digital ones. This research focused on the elements of security and defense in making sure to meet the strategic goals and needs for among others high technology demands for the 2020 World Expo objectives but also the 2021 world technology objectives. This research paper, delivered an analysis and description of a modern day successful, going "smart policy", which potentially can help Dubai turn into becoming also and among others a Silicon Valley of the Arab World.

\section{Endnotes}

${ }^{1}$ The National Business: UAE to Build Egypt's New Cairo, October 26, 2015 [see October 23, 2015].

${ }^{2}$ Dubai Silicon Oasis Authority, Smart, Getting Smarter: https://www.dsoa.ae/en/ smart-city/, [Seen October 26, 2015].

${ }^{3}$ Ibid 2.

${ }^{4}$ Dubai Municipality website: https://www.dm.gov.ae/wps/portal/home [seen October 1 and 12 2015].

${ }^{5}$ Arabian Business, UAE residents say Luxury is a lifestyle: http://www.arabianbusiness.com/uae-residents-say-luxury-is-lifestyle-27174.html [seen October 26th 2015].

${ }^{6}$ UAE National Statistical Information, census 2005-2010, http://www.uaestatistics.gov.ae/ReportPDF/Population\%20Estimates\%202006\%20-\%202010.pdf, [seen October 23, 2015].

${ }^{7}$ Opec.org: http://www.opec.org/opec_web/en/about_us/170.htm

${ }^{8}$ Martin Hvidt, "Public-Private Ties and Their Contribution to Development,", p 562, on Martin Hvidt, Economic and Institutional Reforms in the GCC by the Middle East Institute, Winter 2011, Vol 65. No1, pp86.

${ }^{9}$ UAE National Statistical Information on social issues and standings of living in the UAE, http://www.uaestatistics.gov.ae/EnglishHome/ReportsByDepartmentEnglish/ tabid/104/Default.aspx?MenuId=1\&NDId=364 .[seen on October $25^{\text {th }} 2015$ ]

${ }^{10}$ Dubai the $4^{\text {th }}$ most popular city in the world, Khaleej times, http://www.khaleejtimes.com/article/20150604/ARTICLE/306049885/1037 [seen on October $15^{\text {th }}$ 2015]

${ }^{11}$ UAE interact, Smart Dubai Strategic Plan Launched, 13 June 2014, http:// www.uaeinteract.com/docs/Smart_Dubai_strategic_plan_launched/60399.htm [seen on October 15th 2015] 
${ }^{12}$ Government of Dubai, The official Portal of Dubai Government, http://www.dubai.ae/en/aboutdubai/Pages/DubaiHistory.aspx

${ }^{13}$ Database of Dubai architectural styles, architects and regions, 872 Dubai buildings and monuments, http://www.dubai-architecture.info/

${ }^{14}$ The Executive Council of Dubai: "formed by Law No. 3 for 2003 issued by the late Sheikh Maktoum Bin Rashid Al Maktoum to assist the Ruler in discharging his tasks and exercising his powers. The Council is chaired by His Highness Sheikh Hamdan Bin Mohammed Bin Rashid Al Maktoum, Crown Prince of Dubai, and consists of a number of heads of government entities" http://www.dubai.ae/en/Lists/GovernmentDepartments/DispForm.aspx?ID=51\&category=Government .

${ }^{15}$ Government of Dubai, "Dubai Plan 2021", http://www.dubaiplan2021.ae/dubaiplan-2021/

${ }^{16}$ Harvard Business Review: https://hbr.org/1996/11/what-is-strategy Michael E. Porter 1996, [seen on October 27, 2015]

${ }^{17}$ Ibid 2.

${ }^{18}$ Exposition Information Knowledge: "was the world's first international exposition, which was realized by Prince Albert, the husband of Queen Victoria and President of the Royal Society for the Encouragement of Arts, Manufactures and Commerce. The exposition successfully demonstrated to the world that the United Kingdom, which had been developing steadily since the Industrial Revolution, possessed overwhelming industrial capacity. The number of visitors to the exposition was equivalent to approximately one-third of the total British population at that time. The exposition yielded a profit of approximately 180,000 lb. Moreover,Crystal Palace, a venue building, attracted wide public attention as an exhibit structure" .http://www.ndl.go.jp/exposition/e/s1/1851.html

${ }^{19}$ Ibid 2.

${ }^{20}$ Executive Council of Dubai, http://tec.gov.ae/

${ }^{21}$ The National, http://www.thenational.ae/business/technology/dh1-billion-smartcity-planned-for-dubai-silicon-oasis, Dh1 Billion Smart City Planned for Dubai Silicon Oasis [seen on October 28, 2015].

${ }^{22}$ IRENA: http://www.irena.org/home/index.aspx?PriMenuID=12\&mnu=Pri, International Renewable Energy Agency (IRENA), “The International Renewable Energy Agency (IRENA) is an intergovernmental organization that supports countries in their transition to a sustainable energy future, and serves as the principal platform for international cooperation, a center of excellence, and a repository of policy, technology, resource and financial knowledge on renewable energy. IRENA promotes the widespread adoption and sustainable use of all forms of renewable energy, including bioenergy, geothermal, hydropower, ocean, solar and wind energy, in the pursuit of sustainable development, energy access, energy security and low-carbon economic growth and prosperity", seen on [October 29, 2015]

${ }^{23} \mathrm{UAE}$ to take part to the UN sustainable development summit 2015, http:// www.uaeinteract.com/docs/UAE_to_take_part_in_UN_Sustainable_Development_Summit_2015/71223.htm,[seen on October 27th 2015].

${ }^{24}$ The National, Dubai moves closer to being a smart city, http://www.thenational.ae/ uae/transport/dubai-moves-closer-to-being-smart-city [seen on October 27, 2015].

${ }^{25}$ Gulf News, http://gulfnews.com/news/uae/transport/smart-signals-to-help-easetraffic-in-dubai-1.1549479 Smart Signals to help ease traffic in Dubai [Seen on October 26, 2015] 
${ }^{26}$ Dubai, a new paradigm for Smart Cities, Consulting, KPMG, July 2015 https:// www.kpmg.com/AE/en/Documents/Dubai\%20A\%20new\%20paradigm\%20for\%20smart\%20cities.pdf, [seen on October 20, 2015].

${ }^{27}$ Gulf News, Sheikh Mohammad announces Smart City project to transform Dubai, http://gulfnews.com/news/uae/general/shaikh-mohammad-announces-smart-city-project-to-transform-dubai-1.1244658, [see on October $24^{\text {th }} 2015$ ].

${ }^{28}$ Ibid 17.

${ }^{29}$ Ibid 17.

${ }^{30}$ Ibid 17.

${ }^{31}$ Ibid 17.

${ }^{32}$ Dubai Statistic Center https://www.dsc.gov.ae/en-us

${ }^{33}$ Emirates News Agency, Mohammed Bin Rashid sets up Dubai Center for ESecurity, https://www.wam.ae/en/news/emirates/1395263330809.html [see on October 26th 2015].

${ }^{34}$ mGovernment Magazine, Issue 10 Page 3, http://www.government.ae/html/magazine/issue10/en/files/assets/basic-html/page6.html

${ }^{35}$ National Electronic Security Authority, http://ebdaa.ae/our-services/national-electronic-security-authority-nesa.php [Seen on October 29, 2015].

${ }^{36}$ The 2013 (ISC) 2 Global Information Security Work force study by Frost and Sullivan consulting in Partnership with Booz Allen Hamilton and (ISC)2, by Michael Suby Global Program Director on Information Security, file://C:/Users/Marios/Downloads/ 2013-ISC2-Global-Information-Security-Workforce-Study\%20(3).pdf [seen on October 20, 2015].

${ }^{37}$ Ibid.

${ }^{38}$ Ibid 38.

Competing interests

The author declares that they have no competing interests.

Received: 15 December 2015 Accepted: 21 January 2016

Published online: 27 February 2016

References

Acuto, M., (2010a). Global Cities: Gorillas in Our Midst. Alternatives: Global, Local, Political, 35(4), 425-448. doi:10.1177/ 030437541003500405.

Acuto, M. (2010b). Alternatives: global, local, political. Alternatives, 35(No 4), 425-448.

Ben Brik, A., Rettab, B., \& Mellahi, K. (2011). Market orientation, corporate responsibility and business performance. Journal of Business Ethics, 99(No 3 (Springer)), 307-324.

Meyer, K.E., \& Brysac, S.B. (2011/2012). Kerala: Multiple Improbabilities. World Policy Journal, 28(4), 60-69.

Hvidt, M. (2011). Economic and institutional reforms in the Arab Gulf countries. Middle East Journal, 65(No1 (Middle East Institute)), 85-112.

Lerner, J. (2013). The boulevard of broken dreams: innovation policy and entrepreneurship. Innovation Policy and the Economy, 13(No. 1 (The University of Chicago Press)), 61-82.

News, Gulf. Gulf News. June 11, 2014. http://gulfnews.com/news/uae/government/cyber-security-centre-established-indubai-1.1346144. (accessed October 25, 2015).

Schneider, C. P. (2012). Abu Dhabi and what it means to be a global cultural capital. Georgetown Journal of International Affiars, 13(No2 Summer/Fall 2012 (Georgetown University Press), 99-106. 